Б.Ю. Кассал ${ }^{*}$

Биотические условия плейстоценовой миграции

человека разумного Homo sapiens

на Западно-Сибирскую равнину

DOI: 10.31518/2618-9100-2020-4-1

УДК 639.312.03

Выходные данные для цитирования:

Кассал Б.Ю. Биотические условия плейстоценовой миграции человека разумного Homo sapiens на Западно-Сибирскую равнину // Исторический курьер. 2020. № 4 (12). С. 6-19. URL: http:// istkurier.ru/data/2020/ISTKURIER-2020-4-01.pdf
B.Yu. Kassal*

\section{Biotic Conditions of the Pleistocene Migration of Homo sapiens to the West Siberian Plain}

DOI: $10.31518 / 2618-9100-2020-4-1$

How to cite:

Kassal B.Yu. Biotic Conditions of the Pleistocene Migration of Homo sapiens to the West Siberian Plain // Historical Courier, 2020, No. 3 (11), pp. 619. [Available online:] http://istkurier.ru/data/ 2020/ISTKURIER-2020-4-01.pdf

\begin{abstract}
The penetration of Homo sapiens, an intelligent man, in the ancient Upper Pleistocene 45-40 thousand years ago on the West Siberian Plain occurred along the interfluve and along the rivers. The invasion vector of Homo sapiens was directed from south to north following herds of herbivores migrating from wintering sites to summer pastures. The presence of the Neanderthal genes Homo neanderthalensis in the Homo sapiens genome could contribute to the successful survival and naturalization of humans not so much in the summer as under the harsh winter conditions of the tundra steppe of Western Siberia. The biotic conditions of the tundra steppes contributed to the resettlement of humans in competition with other large predators: cave lions, wolves, small cave bears. The new habitat influenced the formation and development of society, reinforcing the emerging behavioral adaptations of people, including highly productive group hunt for herd hoofed animals on the banks of the Siberian rivers as well as hunting such giants as hairy mammoths. The abundance of hunting prey in the form of a number of representatives of the mammoth megafauna (horses and deer of various species, primitive steppe buffalo, wild bulls, saigas, etc.) provided the emerging human population with the necessary energy from the obtained animal food and building material for winter dwellings and summer shelters. The accumulated experience of people's survival in the tundra-steppe of Western Siberia was preserved by sequential transmission of information from generation to generation, ensuring the survival and success of naturalization under new conditions. Even with a small population, the invasive species Homo sapiens influenced the ecosystem of the tundra steppes of the ancient upper Pleistocene of Western Siberia, which has developed over millennia, but the degree of this influence remains unknown.
\end{abstract}

Keywords: ancient Upper Pleistocene; Western Siberia; biotic conditions; Homo sapiens.

The article has been received by the editor on 31.05.2020.

Full text of the article in Russian and references in English are available below.

Аннотация. Проникновение человека разумного Hoто sapiens в древнем верхнем плейстоцене 45-40 тыс. лет назад на Западно-Сибирскую равнину произошло по междуречьям и вдоль рек. Вектор инвазии Hото sapiens был направлен с юга на север вслед за стадами мигрирующих от мест зимовок к летним пастбищам травоядных животных. Наличие в геноме Homo sapiens генов неандертальца Homo neanderthalensis могло способствовать успешному выживанию и натурализации человека не столько в летних, сколько в суровых

\footnotetext{
* Кассал Борис Юрьевич, кандидат ветеринарных наук, Омский государственный университет им. Ф.М. Достоевского, Омск, Россия, e-mail: BY.Kassal@mail.ru

Kassal Boris Yu., Candidate of Veterinary Sciences, Dostoevsky Omsk State University, Omsk, Russia, e-mail: BY.Kassal@mail.ru
} 
зимних условиях тундростепи Западной Сибири. Биотические условия тундростепей способствовали расселению человека в условиях конкуренции с другими крупными хищниками: пещерными львами, волками, малыми пещерными медведями. Новая среда обитания влияла на формирование и развитие социума, закрепляя появляющиеся поведенческие адаптации людей, в т.ч. в форме высокопродуктивных групповых охот на стадных копытных животных на берегах сибирских рек и на таких гигантов, как волосатые мамонты. Обилие охотничьей добычи в виде ряда представителей мамонтовой мегафауны (лошади и олени разных видов, первобытные степные бизоны, дикие быки, сайгаки и др.), обеспечила формирующуюся человеческую популяцию необходимой энергией из получаемой животной пищи и строительным материалом для зимних жилищ и летних укрытий. Накопленный опыт выживания людей в условиях тундростепи Западной Сибири сохранялся путем последовательной передачи информации от поколения к поколению, обеспечивая выживание и успешность натурализации в новых для них условиях. Даже при малой численности популяции, инвазивный вид Homo sapiens повлиял на сложившуюся за тысячелетия экосистему тундростепей древнего верхнего плейстоцена Западной Сибири, однако степень этого влияния остается неизвестной.

Ключевые слова: древний верхний плейстоцен; Западная Сибирь; биотические условия; Homo sapiens.

Самый древний $(51,8 \pm 4,5 \ldots 54,7 \pm 5,5$ тыс. лет) череп представителя вида человек разумный Homo sapiens за пределами Африки был обнаружен в карстовой пещере Манот (Израиль) в 2008 г. ${ }^{1}$

В 2014 г. на территории Омской области в окрестностях с. Усть-Ишим была найдена самая древняя кость (возраст 45 тыс. лет, древний верхний плейстоцен) человека разумного («усть-ишимского человека») , из которой удалось выделить ДНК, не имевшую фрагментов генома денисовского человека, зато имевшую в геноме $\sim 6$ \% неандертальских генов ${ }^{3}$. При этом известно, что неандерталец был преимущественно мясоедом и обладал большей выносливостью, физической силой и устойчивостью к длительному воздействию низких температур, нежели человек разумный. Вследствие этого закономерно предположение о том, что межвидовой гибрид Homo sapiens $X$ Homo neanderthalensis даже в n-ном поколении обладал достаточной физической устойчивостью для того, чтобы выживать в суровых условиях древнего верхнеплейстоценового климата Западной Сибири.

Примерно к этому же времени ( 40 тыс. л.н., также древний верхний плейстоцен) относится находка костных останков человека разумного в окрестностях с. Байгара Тюменской области ${ }^{5}$. Однако их генетический анализ не проводился.

В древнем верхнем плейстоцене люди были охотниками и собирателями, создавали разнообразные орудия из камня, кости и рога, жилища, шили одежду, создавали скульптуры, гравировки на кости и роге, другие произведения искусства ${ }^{6}$. Будучи всеядным, плейстоце-

\footnotetext{
${ }^{1}$ Hershkovitz I. [et al.]. Levantine cranium from Manot Cave (Israel) foreshadows the first European modern humans // Nature. 2015. Vol. 520. P. 216-219.

${ }^{2}$ Gibbons A. Oldest Homo sapiens genome pinpoints Neandertal input // Science. 2014. No. 343 (6178). P. 1417.

${ }^{3} \mathrm{Fu}$ Q. [et al.] Genome sequence of a 45,000-year-old modern human from western Siberia // Nature. 2014. Vol. 514. P. 445-449; Пэабо C. Неандерталец. В поисках исчезнувших геномов / пер. с англ. Е.Б. Наймарк. М., 2018.

${ }^{4}$ Констэбл Д. Неандертальцы / пер. с англ. И.Г. Гуровой. М., 1978; Шипман П. Захватчики. Люди и собаки против неандертальцев / пер. с англ. Дм. Лазарева. М., 2016.

${ }^{5}$ Ражев Д.И., Косинцев П.А., Кузьмин Я.В. Плейстоценовая таранная кость (os talus) человека с местонахождения Байгара (центр Западной Сибири) // Вестник археологии, антропологии и этнографии. 2010. № 1 (12). С. 119-131.

${ }^{6}$ Жителев Р.А., Кассал Б.Ю. Рог бизона (Bison priscus) в качестве основы многофункционального артефакта // Омская биологическая школа. Ежегодник: межвуз. сб. науч. тр. / под ред. Б.Ю. Кассала. Омск: ОмГПУ, 2012. Вып. 9. С. 149-160.
} 
новый человек разумный употреблял в пищу плоды и корнеплоды, мясо позвоночных животных, яйца птиц и рептилий, подвергая термической обработке значительную часть пищи и тем самым увеличивая ее перевариваемость и энергетическую ценность. Особое значение в питании имели животные жиры, дававшие объемы энергии, столь необходимые для жизни в суровых условиях плейстоценовых тундростепей Западной Сибири. Необходимость освоения разнообразных объектов питания определяла разнообразие способов их добывания и хранения, что стимулировало эволюцию специфических человеческих способностей (развитое сознание, интеллектуальные способности и язык). Для изучения их эволюции необходима интеграция данных различных наук, в т.ч. физической и культурной антропологии, зоопсихологии, этологии, нейрофизиологии, генетики. Имеет смысл дополнение этого перечня данными экологии, поскольку биотические условия обитания всеядного вида в древнем верхнем плейстоцене несомненно влияли на онтогенетическое развитие и реализацию специфических человеческих способностей.

В контексте эволюции, среди других животных человека разумного выделяет качественно новый характер взаимодействия со средой обитания: наряду с пассивным приспособлением к изменяющимся внешним факторам, человек разумный повышал комфортность среды обитания в соответствии со своими потребностями.

Цель данной статьи - оценка биотических условий плейстоценовой миграции человека разумного на Западно-Сибирскую равнину.

Материалы работы были получены автором в процессе полевых исследований в 19762020 гг. на территории Западной Сибири и Северного Казахстана, а также анализа имеющихся архивных данных и их интерпретации с современных экологических позиций.

Регион исследования в работе - Западная Сибирь - часть Сибири, простирающаяся на 2,5 тыс. км от Северного Ледовитого океана до возвышенностей Казахского мелкосопочника и на 1,9 тыс. км от гор Урала до русла р. Енисей. Около 80 \% площади расположено в пределах ЗападноСибирской равнины. Площадь региона - 2451,1 тыс. км² (15 \% территории России) ${ }^{7}$.

Во время последнего оледенения (70-10 тыс. л.н.) ледник накрывал значительную часть территории северной части Западной Сибири. Тундростепи занимали примыкающую к верхнеплейстоценовому леднику обширную полосу, которая перемещалась в соответствии с изменениями границ ледника, к северу или к югу. Экосистемы тундростепей существовали в особых ландшафтно-климатических условиях резко континентального климата с низкими средними температурами и высокой сухостью воздуха. Это сочеталось со значительной обводненностью в летнее время, которая достигалась за счет талых ледниковых вод, подпитывавших многочисленные озера и болота Западной Сибири.

Растительность тундростепей была представлена в основном злаково-осоковыми сообществами, в которых заметно участвовали мхи, мелкие деревца и кустарники. В долинах рек и котловинах по берегам озер развивались зачатки бореальных лесов с преобладанием ольхи, берез, ив, лиственницы и сосны. Вследствие высокой продуктивности преобладающих в растительном покрове тундростепей травянистых растений общая биомасса растительности была очень велика: за короткое жаркое лето вырастало обильное разнотравье, которое солнечная и сухая осень превращала в высококачественное сено на корнюв.

В древнем верхнем плейстоцене тундростепи Западной Сибири представляли обширную экосистему, зоологическими компонентами которой были крупноразмерные позвоночные животные, имевшие значительное распространение и высокую численность. Их совокупность формировала т.н. «мамонтовую мегафауну», поскольку во многом определяющим ее существование был волосатый мамонт Mammothus primigenius.

\footnotetext{
${ }^{7}$ Поспелов Е.М. Сибирь // Географические названия мира: Топонимический словарь / отв. ред. Р.А. Агеева. М., 2002. C. 475.

${ }^{8}$ Флеров К.К. История бизонов и причины изменения их ареалов // История биогеоценозов СССР в голоцене. М., 1976. С. 166-175; Флеров К.К. Основные черты формирования фауны млекопитающих четвертичного периода в северном полушарии // Тр. Комиссии по изучению четвертичного периода. 1955. Т. 12. С. 121-126.
} 
Изобилие крупных млекопитающих оказывало существенное влияние на формирование и эволюцию биоценозов тундростепи. Для всех животных мамонтовой мегафауны были характерны приспособления к жизни в условиях низких температур: длинная и густая шерсть, накопление толстого слоя подкожного жира, устойчивость к низким температурам и длительным голоданиям, крупные размеры и большая масса тела, специфические поведенческие приспособления 9.

Судя по известным костным останкам на территории Западной Сибири, в плейстоценовых тундростепях наиболее многочисленными были лошадь Пржевальского Equus przewalskii, степной тарпан E. gmelini gmelini, а летом - кулан E. hemionus. Столь же многочислен был первобытный степной бизон Bison priscus, объединявшийся в большие стада. Северный олень Rangifer tarandus, видимо, был еще многочисленнее, однако некрупные кости оленя съедались хищниками и падальщиками, поэтому достоверно судить о его численности по костным останкам не приходится ${ }^{10}$.

В составе мамонтовой мегафауны были виды, которые обитали на территории ЗападноСибирской равнины постоянно (оседло) или совершали незначительные сезонные миграции в широтном и долготном направлениях, и те, кто приходил на равнину лишь на лето, а к зиме совершал значительные по протяженности миграции и выселялся на юг, за ее пределы. Долготные сезонные миграции стадных травоядных животных происходили по водоразделам и по долинам рек, однако протяженность этих миграций лишь предположительна. Широтные перемещения по водораздельным равнинам, внутрисезонные кочевки по междуречьям давали возможность полноценного использования экологических возможностей разнообразных биотопов, а пересечение стадами рек - возможность освоения еще не стравливаемых пастбищ.

Представители мамонтовой мегафауны на открытых пространствах тундростепи постоянно не жили, они появлялись там только в то время в теплый период года, когда ветер сдувал прочь кровососущих насекомых, и можно было спокойно пастись и отдыхать, одновременно издали замечая приближающихся хищников ${ }^{11}$. На зиму же травоядные, а следом за ними и хищные звери, перемещались в поймы многочисленных рек и речушек, в котловины на берега озер, в заросли кустарников, выходя оттуда на кормежку на открытые места лишь там, где снежный покров был не настолько глубок, чтобы из-под него нельзя было достать прошлогоднюю траву и ветки карликовых деревьев и кустарников. Это было необходимо, поскольку в местах отстоя (дневок и ночевок) в понижениях рельефа, куда с открытых мест сметало много снега, было комфортно отдыхать под защитой образующихся сугробов, но кормиться там было весьма затруднительно.

Животные некоторых видов на зимний период покидали Западно-Сибирскую равнину и совершали протяженные миграции, уходя далеко на юг, в зону холмистых равнин, в долины и предгорья Алтая, Чу-Илийских гор и Киргизского Ала-Тоо, на берега КаспийскоАральского моря. Так поступали степные первобытные бизоны, сайгаки Saiga tatarica, некоторые другие травоядные; по ископаемым остаткам заходы сайгаков известны на север до берегов р. Тары (около 56,5 N). Именно вслед за такими стадами в древнем верхнем плейстоцене в весенне-летние периоды произошло проникновение человека разумного на Западно-Сибирскую равнину. Наличие в его геноме генов неандертальца могло способствовать дальнейшей успешной натурализации человека разумного в суровых условиях тундростепей Западной Сибири.

\footnotetext{
${ }_{9}^{9}$ Формозов А.Н. Снежный покров в жизни млекопитающих и птиц. М., 1990; Флеров К.К. История бизонов и причины изменения их ареалов // История биогеоценозов СССР в голоцене. М., 1976. С. 166-175; Флеров К.К. Основные черты формирования фауны млекопитающих четвертичного периода в северном полушарии // Тр. Комиссии по изучению четвертичного периода. 1955. Т. 12. С. 121-126.

${ }^{10}$ Кассал Б.Ю. «Осколки» плейстоценовой мегафауны в степях Среднего Прииртышья // Степной бюллетень, 2014 (осень), № 42. С. 45-51.

${ }^{11}$ Баскин Л.М. Особенности морфологии и экологии лесных и тундровых северных оленей // Лесной северный олень Фенноскандии. Петрозаводск, 1989. С. 86-91; Флеров К.К. История бизонов... С. 166-175; Флеров К.К. Основные черты формирования фауны млекопитающих... С. 121-126.
} 
Большерогий олень Megaloceros giganteus, широколобый лось Cervalces postremus, тур (дикий бык) Bos taurus primigenius, малочисленные зоргелии Soergelia sp. и бараны Ovis ammon, некоторые другие травоядные держались в основном в речных поймах и в котловинах по берегам крупных и мелких озер, где проводили большую часть годового цикла. Шерстистый носорог Coelodonta antiquitatis, овцебык Ovobos moschatus, волосатый мамонт проводили зимовку в речных поймах, а на летовку выселялись на водораздельные равнины. суслики Spermophilus sp., сурки Marmota sp., зайцы Lepus sp. и многие другие некрупные звери были распространены повсеместно. В древнем верхнем плейстоцене эти животные были многочисленными современниками человека разумного. Однако охота на такую некрупную дичь обычно становилась прерогативой детей и подростков, оттачивающих в этом процессе свое охотничье мастерство и навыки владения охотничьим оружием. Тогда как взрослые мужчины предпочитали охотиться на крупную дичь, что было энергетически выгоднее и обеспечивало соплеменников мясом относительно надолго ${ }^{12}$ (рис. 1).

Следом за перемещающимися по равнине мигрирующими травоядными животными кочевали хищники. Относительно оседлый образ жизни на территории Западной Сибири вели немногочисленные пещерная гиена Crocuta crocuta spelaea и малый пещерный медведь Ursus rossicus ${ }^{13}$. Среди волков Canis lupus были оседлые особи, круглогодично жившие семьями на одной и той же территории, и кочевые, перемещавшиеся вслед за стадами травоядных животных, пересекавшие участки оседлых волчьих семей и вступавшие с ними в территориальные отношения и конкуренцию за пищу ${ }^{14}$. О кочевках в долготном направлении на значительные расстояния пещерных львов Panthera leo spelaea достоверно ничего не известно. Их ближайшие родственники - азиатские и африканские львы разных подвидов живут оседло прайдами, но при этом некоторые самцы способны совершать дальние кочевки вследствие высокой плотности населения и недостатка корма. По аналогии, часть пещерных львов, особенно несемейных, также могла кочевать за стадами травоядных животных.

В добывании корма между травоядными животными мамонтовой мегафауны в тундростепях в древнем верхнем плейстоцене складывались определенные экологические и поведенческие отношения. Существенное значение они приобретали в зимний период, наиболее тяжелый для выживания в суровых условиях Западной Сибири.

Ключевая роль в добывании корма на междуречьях зимой принадлежала волосатым мамонтам, которые пробивали собой толщу снега и в подходящих местах бивнями разгребали снег до самой земли, добывая травянистый и веточный корм карликовых деревьев и кустарников. Следом за ними шли бизоны, северные олени, овцебыки, выедая ту относительно высокорослую траву, которую не съели мамонты. Последними в этой цепочке двигались лошади (степные тарпаны и лошади Пржевальского), выщипывая до мерзлой земли не съеденые бизонами и оленями засохшие растения. В результате на освобожденных мамонтами от снега участках трава и кустарники съедались до основания, а деревья - до обглоданных стволиков. При этом олени и лошади увеличивали площади таких участков, по их периферии самостоятельно разгребая снег копытами в процессе тебеневки. Следующим летним сезоном на этих участках вновь отрастала трава и поднимались побеги кустарников; использование участков тундростепи травоядными животными носило мозаичный (локальный) характер, пятнистый или ленточный.

\footnotetext{
${ }^{12}$ Кассал Б.Ю. Культура загонных групповых охот в традиционном обществе неолита // Традиционные общества: неизвестное прошлое: мат-лы XV Междунар. науч.-практ. конф., г. Челябинск, 15.05.2019 / под ред. П.Б. Уварова (гл. ред.). Челябинск, 2019. С. 220-228.

${ }^{13}$ Кассал Б.Ю. «Осколки» плейстоценовой мегафауны...

${ }^{14}$ Воробьевская Е.А., Бондарев А.Я., Суворов А.П., Политов Д.В. Исследования филогеографии волка (Сапіs lupus L.) Южной Сибири и Красноярского края методом микросателлитных маркеров // Териофауна России и сопредельных территорий: междунар. совещание (IX съезд Териологического общества при РАН). М., 2011. С. 104.
} 


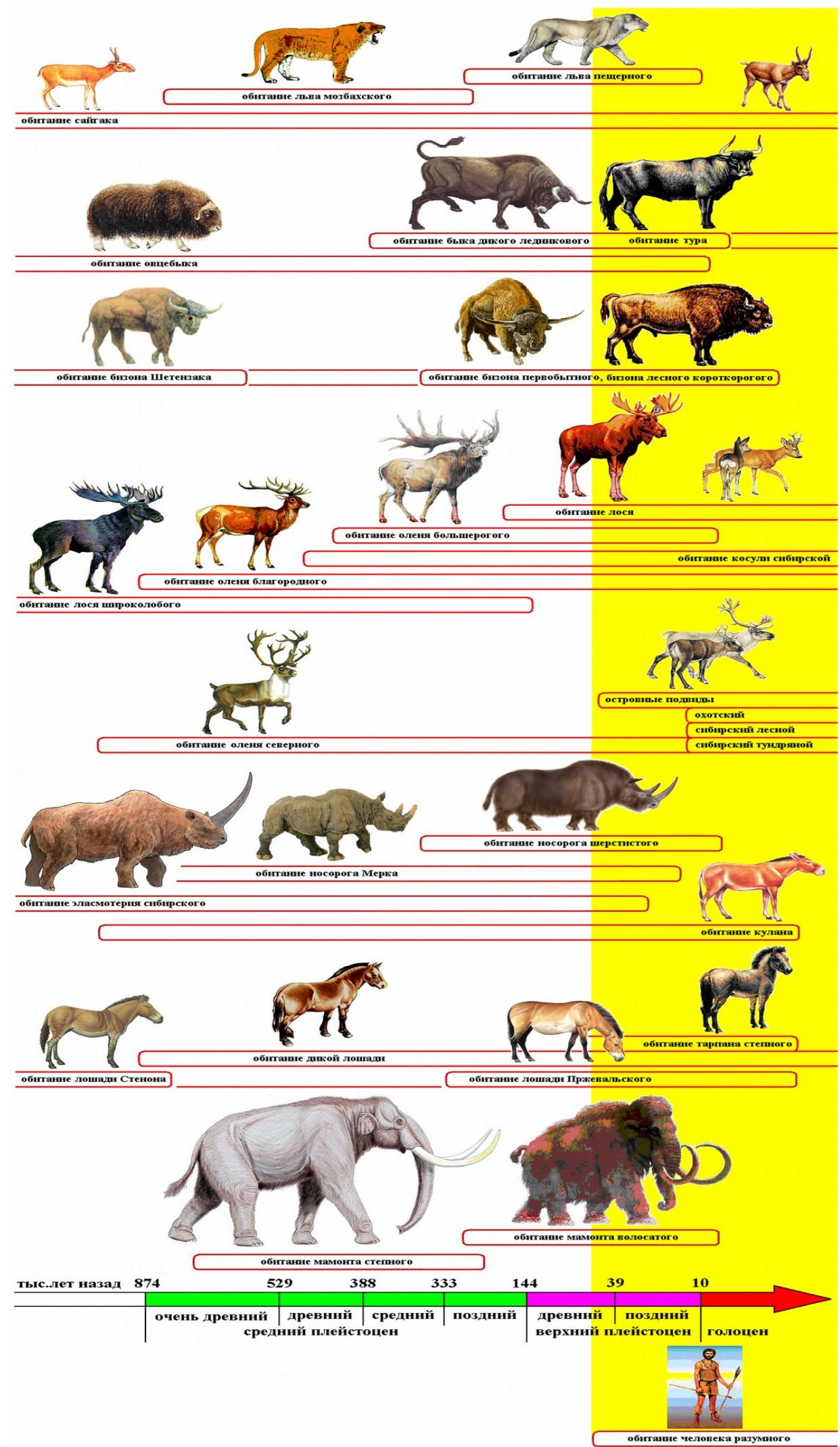

Puc. 1. Время существования основных видов мамонтовой мегафауны в Западной Сибири. Хронология дана по шкале Н. Шеклтона ${ }^{15}$. Фигуры показаны в едином масштабе. Линейки соответствуют геологической продолжительности существования видов. Тонированное поле - период существования в Западной Сибири человека разумного.

${ }^{15}$ Shackleton N.J. The stratigraphic record of deep-sea cores and its implications for the assessment of glacials, interglacials, stadials, and interstadials in the mid-Pleistocene // After the Australopithecines: Stratigraphy, ecology, and culture change in the Middle Pleistocene. Hague: Mouton Publishers. 1975. P. 1-24. 
В древесно-кустарниковых зарослях в котловинах на берегах озер и в поймах рек в зимнее время складывалась аналогичная картина последовательного освоения растительного корма, но ведущим видом там был шерстистый носорог. Носороги пробивали тоннели в снегу от одного кустарникового массива-«острова» до другого, и выедали траву под кустарниками и деревьями, используя для разгребания снега свой передний рог. По пробитым в снегу коридорам перемещались другие животные, олени и лоси объедали древесно-кустарниковые побеги, которые шерстистому носорогу были менее интересны, чем трава под ногами. Тут же паслись косули Capreolus pygargus и зайцы ${ }^{16}$ (рис. 2).

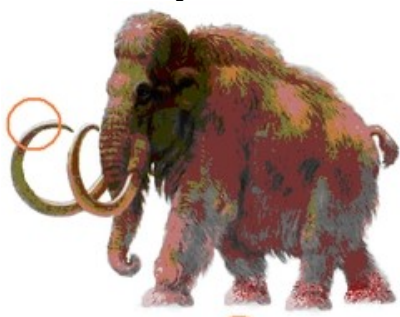

1

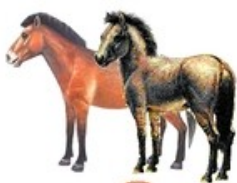

2

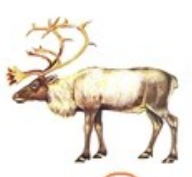

3

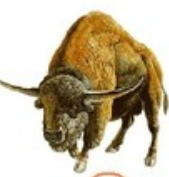

(4)

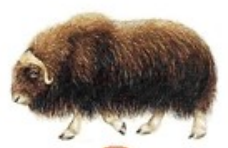

5

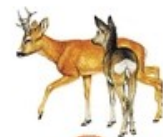

急

6

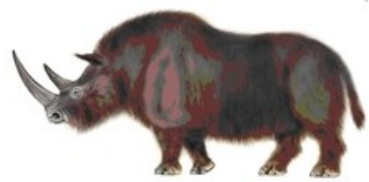

(A)

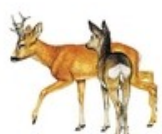

(5)

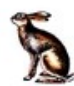

(B)

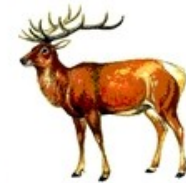

(r)

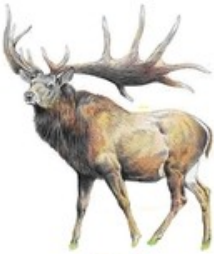

(A)

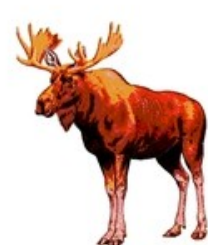

(E)

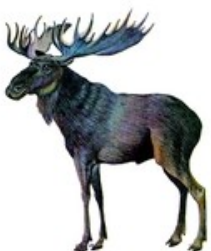

ж

Puc. 2. Очередность зимнего освоения травяного (вверху) и веточного (внизу) корма млекопитающими мамонтовой мегафауны в тундростепях Западной Сибири, древний верхний плейстоцен (Авт.):

1 - волосатый мамонт Mammuthus primigenius; 2 - степной тарпан Equus gmelini и лошадь Пржевальского

Equus przewalskii; 3 - северный олень Rangifer tarandus; 4 - первобытный степной бизон Bison priscus;

5 - овцебык Ovobos moschatus; 6, Б - косуля Capreolus pygargus; 7, В - зайцы Lepus sp.;

A - шерстистый носорог Coelodonta antiquitatis; Г - благородный олень Cervus elaphus;

Д - большерогий олень Megalocervus giganteus; Е - обыкновенный лось Alces alces;

Ж - широколобый лось Cervalces latifrons. Фигуры показаны в едином масштабе.

Такая последовательность зимнего кормления позволяла животным полноценно осваивать ограниченные в зимний период топические и трофические ресурсы. В условиях очередности зимнего кормления, вслед за продвигающимися в глубоком снегу шерстистыми носорогами, за разгребающими снег волосатыми мамонтами и тебенюющими лошадьми другие травоядные получали возможность добывать корм из-под снега с такой глубины, с какой самостоятельно извлечь его не могли.

При этом травоядные животные являлись объектом хищничества со стороны волка, малого пещерного медведя, пещерного льва, пещерной гиены, росомахи Gulo gulo, а также ряда менее крупных хищников, поедающих не только ослабленных и больных животных, но и падаль. Из-за сезонной специфичности размещения и перемещения по территории самих хищников и объектов их добычи зимние и летние рационы хищников также различались. Наряду с волком, пещерным львом, пещерной гиеной, в процессе натурализации человек разумный вошел в число сверххищников тундростепной экосистемы Западной Сибири, составляя трофическую конкуренцию этим видам.

Несомненно, многочисленные представители основных видов мамонтовой мегафауны вместе с менее многочисленными животными выедали и вытаптывали растительность и удобряли почву навозом, обеспечивая круговорот биогенных веществ и функционирование экосистемы тундростепи древнего верхнего плейстоцена Западной Сибири.

Расселяющийся на Западно-Сибирской равнине человек разумный неизбежно влиял на существовавшие биоценозы тундростепей, для того времени будучи инвазивным видом,

\footnotetext{
${ }^{16}$ Кассал Б.Ю. 60 секунд по парку, которого не было (XXI путешествие омского натуралиста). Омск, 2009. 166 с.
} 
чуждым для сложившейся экосистемы. Встраивание человека в существовавшие биоценозы неизбежно влекло трансформацию мамонтовой фауны, тем большую, чем большей была его избирательность в добывании животных определенных видов, и чем выраженнее была конкуренция человека разумного и хищников - компонентов экосистемы древних верхних плейстоценовых тундростепей. Таким образом, в процессе инвазии человека разумного в тундростепи Западной Сибири он проявлял антибиоз ко всем видам мамонтовой мегафауны, в форме хищничества относительно травоядных животных, в форме межвидовой конкуренции - относительно хищников и падальщиков (рис. 3).

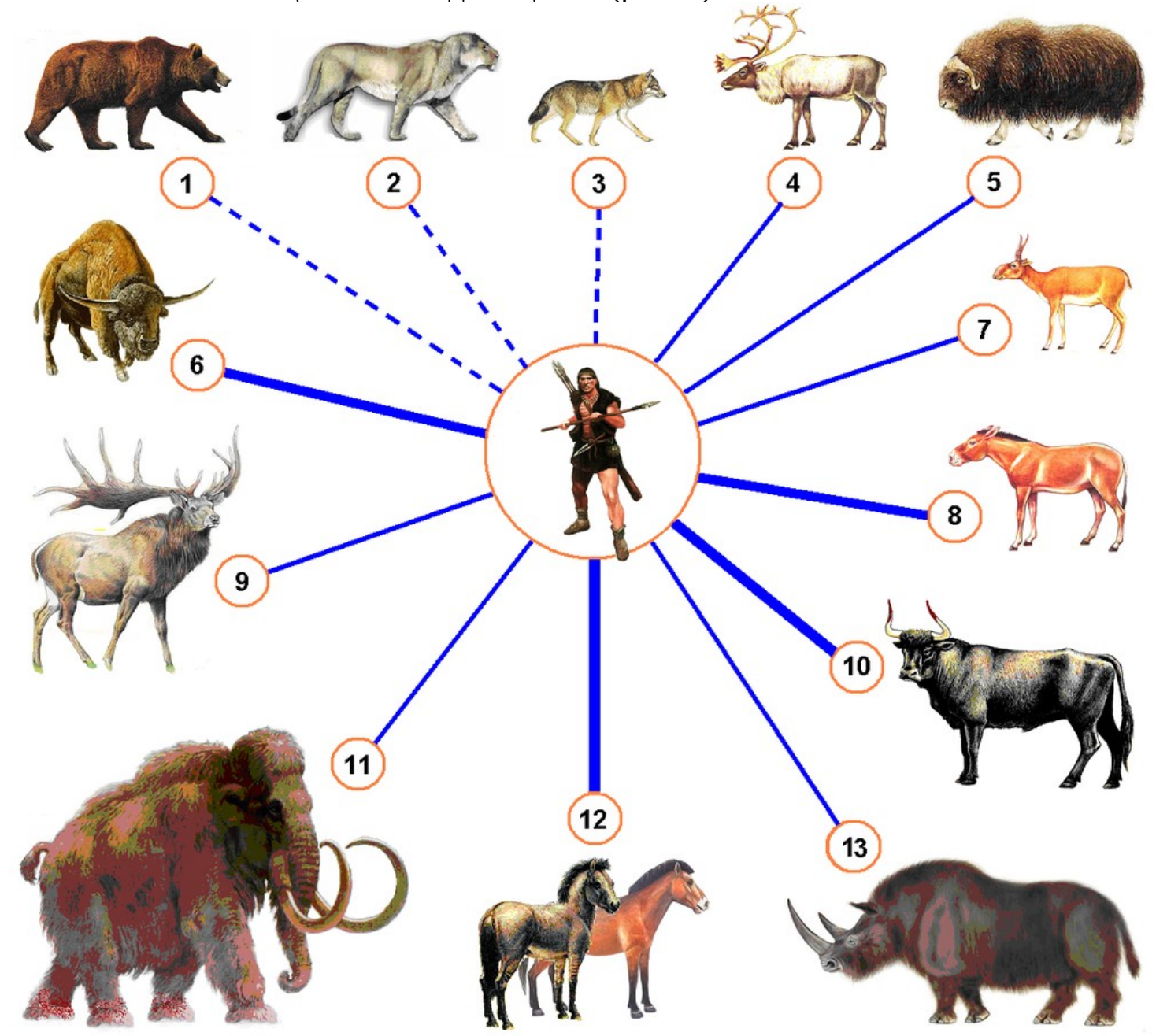

Puc. 3. Отношения антибиоза человека разумного Homo sapiens с млекопитающими мамонтовой мегафауны в тундростепях Западной Сибири, древний верхний плейстоцен (Авт.): 1 - медведь пещерный малый Ursus rossicus; 2 - лев пещерный Panthera leo spelaea; 3 - волк Canis lupus; 4 - олень северный Rangifer tarandus;

5 - овцебык Ovibos moschatus; 6 - бизон степной первобытный Bison priscus; 7 - сайгак Saiga tatarica;

8 - кулан Equus hemionus; 9 - олень большерогий Megaloceros giganteus; 10 - тур, дикий бык Bos primigenius;

11 - мамонт волосатый Mammuthus primigenius; 12 - лошади: тарпан степной Equus gmelini и лошадь Пржевальского Equus przewalskii; 13 - носорог шерстистый Coelodonta antiquitatis.

Толстыми линиями указаны связи антибиоза в форме хищничества для приоритетных охотничьих объектов, тонкими - для викарных охотничьих объектов; прерывистыми линиями указаны связи антибиоза в форме межвидовой конкуренции с хищниками и падальщиками. Фигуры показаны в едином масштабе.

Приоритетной добычей человека разумного в тундростепях Западной Сибири были стадные травоядные копытные, наиболее многочисленные ${ }^{17}$; получаемые от них животные

\footnotetext{
${ }^{17}$ Бондарев А.А., Кассал Б.Ю. Териофауна и природные комплексы плейстоцена Верхнеошской палеодолины // Труды зоологической комиссии ОРО РГО. Ежегодник: межвуз. сб. науч. тр. / под ред. Б.Ю. Кассала. Омск, 2004. Вып. 1. С. 149-158; Бондарев А.А., Кассал Б.Ю. Плейстоценовая териофауна Крутинского района Омской области // Естественные науки и экология. Ежегодник: межвуз. сб. науч. тр. Омск, 2005. Вып. 9. С. 91-97; Бондарев А.А., Кассал Б.Ю. История и перспективы развития териофауны Среднего Прииртышья // Вестник Оренбургского государственного университета. 2009 (июнь). № 6 (100). С. 86-88.
} 
продукты служили основой создания зимних запасов, сохраняемых в условиях мерзлотной почвы, а также получения строительного материала (крупные кости и шкуры) и топлива (некрупные кости), кожевенного сырья для изготовления одежды и костного сырья для изготовления охотничьего оружия.

Культура охоты на волосатого мамонта требовала от охотников плейстоцена знания анатомии зверя, его биологии и этологии. Основными способами его добычи были: провокация развития перитонита вследствие нанесения проникающих ранений брюшной стенки в области живота и промежности; парентеральное введение растительных ядов с обработанных наконечников копий; провокация болевого шока и смертельной кровопотери путем нанесения многочисленных колото-резаных ран лицевой части головы, в т.ч. хобота и глаз ${ }^{18}$. В реализации таких способов добычи мамонта участвовали члены одного рода - одной или двух-трех родственных между собой семей. Для проведения загонных групповых охот на крупных копытных животных могло потребоваться большее количество участников, но также вероятно, что их могли проводить и в составе одного рода, учитывая разобщенность семей и низкую плотность населения человека разумного на территории тундростепей.

Наиболее вероятно, что культура загонных групповых охот на крупных копытных животных на крутых берегах сибирских рек начала формироваться именно в древнем верхнем плейстоцене, в условиях очень высокой численности объектов охоты ${ }^{19}$. Эта культура включила в себя комплекс знаний и навыков по управлению стадами крупных копытных животных, имевших существенные нюансы для разных видов - лошадей, бизонов и др.; использование охотничьего оружия для нанесения животному несовместимых с жизнью травм; умение направить стадо к речному обрыву и сталкивание животных вниз; использование способов массового разделывания значительного количества жертв, массовой заготовки мясных продуктов и шкур с их последующим применением ${ }^{20}$.

Роли участников групповых охот распределялись в соответствии с возрастом и социальным статусом: каждый член рода знал свою роль, подтверждаемую вождями - зрелыми мужчинами и старейшинами. Опытные (пожилые) охотники выполняли роль регулировщиков движения табуна лошадей или стада первобытных степных бизонов. Зрелые мужчины и прошедшие посвящение в охотники юноши препятствовали убегающим прочь от обрыва между логами-оврагами животных. Первичная обработка добычи (снятие шкур, потрошение, разделывание туши на части) выполнялась женщинами и подростками обоего пола; долговременная заготовка продуктов (подготовка ливера к поеданию, нарезание мяса полосами, его сушка и изготовление пеммикана, квашение мяса в каких-либо емкостях и др.) выполнялась молодыми и зрелыми женщинами, которым помогали дети и пожилые женщины. По окончании охоты зрелые и пожилые мужчины использовали фрагменты добычи (кости, рога, сухожилия, волосы, кожу и др.) для изготовления оружия и предметов быта. Психологический настрой на удачную охоту и завершающие торжества выполнял шаман, независимо от его возраста, при участии всех членов рода ${ }^{21}$.

Стремление приспособить новую для себя среду обитания - тундростепи древнего верхнего плейстоцена Западной Сибири - для своих потребностей подвигла человека разумного

\footnotetext{
${ }^{18}$ Кассал Б.Ю. Охота на мамонта как легенда культуры // Вестник Омского государственного педагогического университета, Гуманитарные исследования. 2020. № 1 (26). С. 14-18.

${ }^{19}$ Кассал Б.Ю. Дикие копытные на степной территории Среднего Прииртышья // Степной бюллетень. $2014 \mathrm{a}$. № 40. С. 44-47; Кассал Б.Ю. Дикие лошади Среднего Прииртышья // Табунное коневодство на юге Средней Сибири: мат-лы науч.-практ. конф. (5-8 августа 2014 г., г. Абакан) / ФАНО РФ, ФГБНУ «НИИ аграрных проблем Хакасии», ФГБНУ «ВНИИ коневодства», ФГБНУ «Тувинский НИИ сельского хозяйства», ФГБОУ ВПО «Тувинский ГУ», 2014б. Абакан, 2014б. С. 39-43.

${ }^{20}$ Кассал Б.Ю. Практика загонных групповых охот на берегах сибирских рек в плейстоцене // Омский научный вестник. Серия «Общество. История. Современность». 2016. № 1. С. 38-48; Кассал Б.Ю. Культура загонных групповых охот в традиционном обществе неолита // Традиционные общества: неизвестное прошлое: мат-лы XV Междунар. науч.-практ. конф., г. Челябинск, 15.05.2019 / под ред. П.Б. Уварова (гл. ред.). Челябинск, 2019. C. 220-228.

${ }^{21}$ Кассал Б.Ю. Роли участников загонных групповых охот в обществе неолита // ХІІІ Конгресс антропологов и этнологов России: сб. мат-лов. Казань, 2-6 июля 2019 г. / отв. ред. М.Ю. Мартынова. М., 2019. С. 149.
} 
к устройству искусственных укрытий и жилищ. Невозможность устраивать свои жилища в пещерах (за их отсутствием) потребовала от человека развития умений оборудовать зимние жилища в логах и в нишах речных обрывов; летние жилища на плакоре имели временный характер и служили лишь для укрытии на ночь и от дождя. Для зимних стационарных и летних временных жилищ могли использоваться не только (и не столько, ввиду скудости древесной растительности в тундростепях) стволов и ветвей деревьев, но и крупных костей животных, в частности волосатого мамонта и шерстистого носорога. Более того, наиболее вероятно, что летние жилища из года в год устраивались в тех местах, где не только наблюдалось постоянное обилие потенциальной добычи, при наличии доступных источников воды, но и куда людьми стаскивался из ближайших окрестностей и там накапливался подходящий материал для строительства каркасов жилищ, накрываемых звериными шкурами. Менее значимые костные остатки использовались в качестве топлива для костра.

Человек разумный времен древнего верхнего плейстоцена успешно натурализовался в экосистеме тундростепи Западной Сибири. Но условия его жизни неизбежно менялись в процессе продолжающейся многовековой охоты на представителей мамонтовой мегафауны (рис. 4).

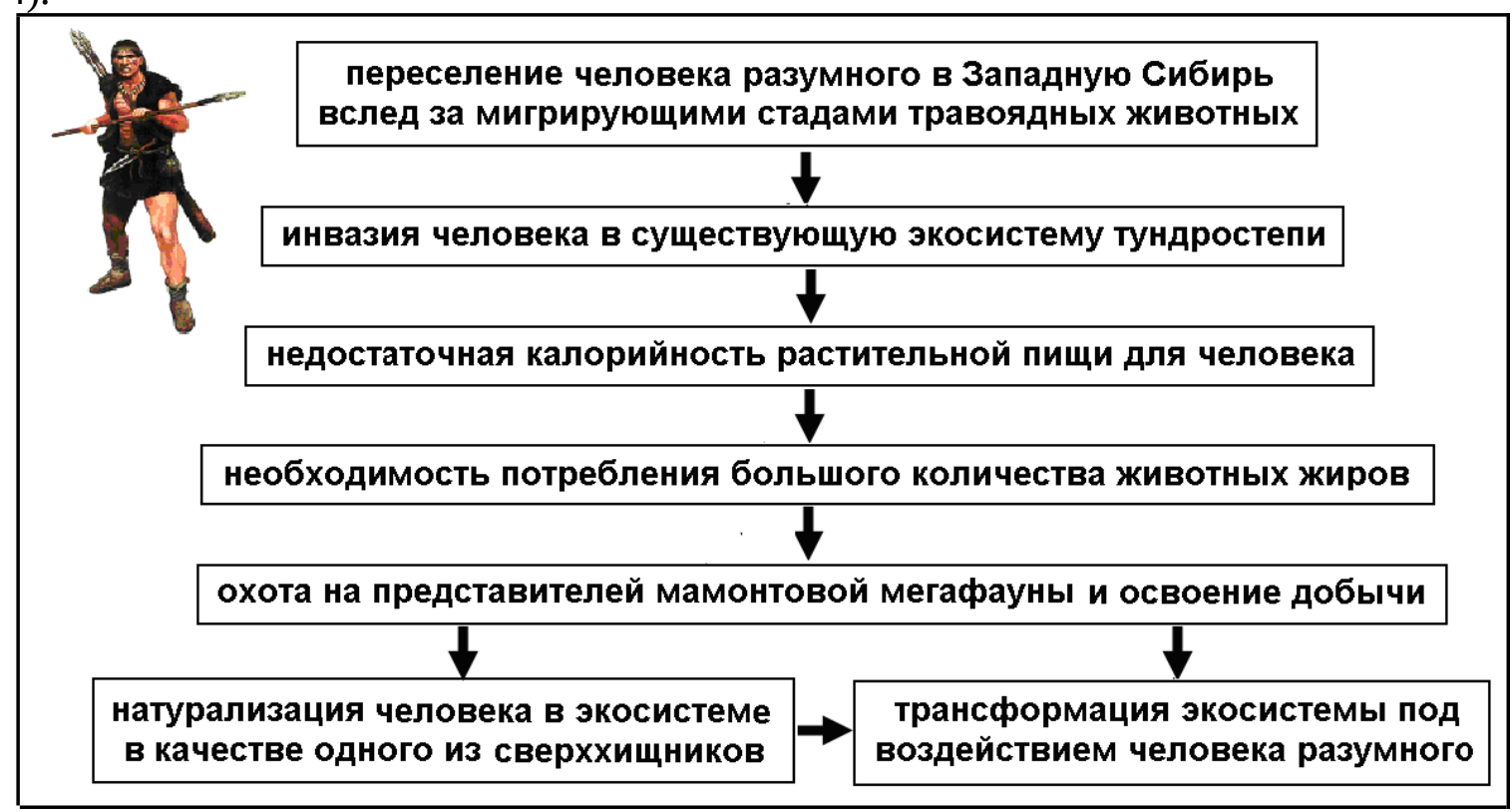

Puc. 4. Причинно-следственные связи инвазии человека разумного и трансформации экосистемы тундростепи в древнем верхнем плейстоцене Западной Сибири (Авт.).

Предполагается четыре причины трансформации мамонтовой мегафауны в тундростепях Западной Сибири: изменения климата; эпизоотии (панзоотии); деструктивная деятельность охотников, падение астероида или кометы с последующим глобальным изменением климата планеты. Однако это разного приоритета причины одного события ${ }^{22}$. Согласно данным, подтверждающим падение метеорита в Мексике около 13 тыс. л.н. ${ }^{23}$, именно космическая катастрофа обусловила окончание на планете последнего ледникового максимума и послужила причиной изменения планетарного климата, и как одно их следствий - массового вымирания мамонтовой мегафауны в Западной Сибири.

С началом голоцена, в измененных условиях существования человека разумного, некоторое время сохранялось изобилие пищи (объектов охоты и собирательства) и увеличились возможности ее освоения. Это повлекло за собой относительно кратковременный рост численности населения людей в Западной Сибири и сохранило у них присваивающий тип деятельности. Таяние плейстоценового ледника, заболачивание громадных территорий

\footnotetext{
${ }^{22}$ Koch P.L., Barnosky A.D. Late Quaternary extinctions: state of the debate // Ann. Rev. Ecol. Evol. Syst., 2006. P. 215-250; Gill J.L. [et al.] Pleistocene megafaunal collapse, novel plant communities, and enhanced fire regimes in North America // Science. 2009. No. 326 (5956). P. 1100-1103.

${ }^{23}$ Israde-Alcántara I. [et al.]. Evidence from central Mexico supporting the Younger Dryas extraterrestrial impact hypothesis // Proceedings of the National Academy of Sciences. 2012. No. 109 (13). P. E738-E747.
} 
Западно-Сибирской равнины, развитие зоны лесов, постепенное исчезновение большинства видов мамонтовой мегафауны и распространение животных иных видов потребовало от человека разумного новых приспособлений к новым условиям обитания.

По результатам исследования можно сделать следующие выводы.

1. Проникновение человека разумного Homo sapiens в древнем верхнем плейстоцене на Западно-Сибирскую равнину произошло по междуречьям и вдоль рек вслед за стадами мигрирующих травоядных животных. Наличие в его геноме генов неандертальца Ното neanderthalensis могло способствовать успешной натурализации человека в суровых условиях тундростепей.

2. Биотические условия тундростепей способствовали расселению человека. Новая среда обитания влияла на формирование и развитие его социума. Обилие охотничьей добычи в виде ряда представителей мамонтовой мегафауны обеспечило формирующуюся человеческую популяцию необходимой энергией из получаемой животной пищи и строительным материалом для зимних жилищ и летних укрытий. Накопленный опыт сохранялся путем последовательной передачи информации от поколения к поколению, обеспечивая выживание и успешность натурализации.

3. Как инвазивный вид, даже при малой численности популяции, человек разумный повлиял на экосистему тундростепей древнего верхнего плейстоцена Западной Сибири, однако степень этого влияния остается неизвестной.

\section{Лumepamypa}

Баскин Л.М. Особенности морфологии и экологии лесных и тундровых северных оленей // Лесной северный олень Фенноскандии. Петрозаводск: КФАН СССР, 1989. С. 86-91.

Бондарев А.А., Кассал Б.Ю. Териофауна и природные комплексы плейстоцена Верхнеошской палеодолины // Труды зоологической комиссии ОРО РГО. Ежегодник: межвуз. сб. науч. тр. / под ред. Б.Ю. Кассала. Омск: Издатель-Полиграфист, 2004. Вып. 1. С. 149-158.

Бондарев А.А., Кассал Б.Ю. Плейстоценовая териофауна Крутинского района Омской области // Естественные науки и экология. Ежегодник: межвуз. сб. науч. тр. Омск: ОмГПУ, 2005. Вып. 9. С. 91-97.

Бондарев А.А., Кассал Б.Ю. История и перспективы развития териофауны Среднего Прииртышья // Вестник Оренбургского государственного университета. 2009 (июнь). № 6 (100). C. $86-88$.

Воробьевская Е.А., Бондарев А.Я., Суворов А.П., Политов Д.В. Исследования филогеографии волка (Canis lupus L.) Южной Сибири и Красноярского края методом микросателлитных маркеров // Териофауна России и сопредельных территорий: междунар. совещание (IX съезд Териологического общества при РАН). М.: ТНИ КМК, 2011. С. 104.

Жителев Р.А., Кассал Б.Ю. Рог бизона (Bison priscus) в качестве основы многофункционального артефакта // Омская биологическая школа. Ежегодник: межвуз. сб. науч. тр. / под ред. Б.Ю. Кассала. Омск: ОмГПУ, 2012. Вып. 9. С. 149-160.

Кассал Б.Ю. 60 секунд по парку, которого не было (XXI путешествие омского натуралиста). Омск: Первопечатник, 2009. 166 с.

Кассал Б.Ю. «Осколки» плейстоценовой мегафауны в степях Среднего Прииртышья // Степной бюллетень, 2014 (осень), № 42. С. 45-51.

Кассал Б.Ю. Дикие копытные на степной территории Среднего Прииртышья // Степной бюллетень. 2014. № 40. С. 44-47.

Кассал Б.Ю. Дикие лошади Среднего Прииртышья // Табунное коневодство на юге Средней Сибири: мат-лы науч.-практ. конф. (5-8 августа 2014 г., г. Абакан) / ФАНО РФ, ФГБНУ «НИИ аграрных проблем Хакасии», ФГБНУ «ВНИИ коневодства», ФГБНУ «Тувинский НИИ сельского хозяйства», ФГБОУ ВПО «Тувинский ГУ». Абакан, 2014. С. 39-43. 
Кассал Б.Ю. Практика загонных групповых охот на берегах сибирских рек в плейстоцене // Омский научный вестник. Серия «Общество. История. Современность». 2016. № 1. C. 38-48.

Кассал Б.Ю. Культура загонных групповых охот в традиционном обществе неолита // Традиционные общества: неизвестное прошлое: мат-лы XV Междунар. науч.-практ. конф., г. Челябинск, 15.05.2019 / под ред. П.Б. Уварова (гл. ред.). Челябинск: Изд-во Южно-Урал. гос. гуман.-пед. ун-та. 2019. С. 220-228.

Кассал Б.Ю. Охота на мамонта как легенда культуры // Вестник Омского государственного педагогического университета, Гуманитарные исследования. 2020. № 1 (26). С. 14-18.

Кассал Б.Ю. Роли участников загонных групповых охот в обществе неолита // XIII Конгресс антропологов и этнологов России: сб. мат-лов. Казань, 2-6 июля 2019 г. / отв. ред. М.Ю. Мартынова. М.; Казань: ИЭА РАН, КФУ, Институт истории им. Ш. Марджани АН РТ, 2019. С. 149.

Констэбл Д. Неандертальцы / пер. с англ. И.Г. Гуровой. М.: Мир, 1978. 160 с.

Поспелов Е.М. Сибирь // Географические названия мира: Топонимический словарь / отв. ред. Р.А. Агеева. М.: Русские словари, Астрель, АСТ, 2002. С. 475.

Пэабо С. Неандерталец. В поисках исчезнувших геномов / пер. с англ. Е.Б. Наймарк. М.: АCT, 2018. 416 с.

Ражев Д.И., Косинцев П.А., Кузьмин Я.В. Плейстоценовая таранная кость (os talus) человека с местонахождения Байгара (центр Западной Сибири) // Вестник археологии, антропологии и этнографии. 2010. № 1 (12). С. 119-131.

Флеров К.К. История бизонов и причины изменения их ареалов // История биогеоценозов СССР в голоцене. М.: Наука, 1976. С. 166-175.

Флеров К.К. Основные черты формирования фауны млекопитающих четвертичного периода в северном полушарии // Тр. Комиссии по изучению четвертичного периода. 1955. Т. 12. С. 121-126.

Формозов А.Н. Снежный покров в жизни млекопитающих и птиц. М.: МГУ, 1990. 286 с.

Шипман П. Захватчики. Люди и собаки против неандертальцев / пер. с англ. Дм. Лазарева. М.: Альпина нон-фикшн; Издательство ЛКИ, 2016. 296 с.

$\mathrm{Fu} \mathrm{Q}$. [et al.]. Genome sequence of a 45000 -year-old modern human from western Siberia // Nature. 2014. Vol. 514. P. 445-449.

Gibbons A. Oldest Homo sapiens genome pinpoints Neandertal input // Science. 2014. № 343 (6178). P. 1417.

Gill J.L. [et al.]. Pleistocene megafaunal collapse, novel plant communities, and enhanced fire regimes in North America // Science. 2009. № 326 (5956). P. 1100-1103.

Hershkovitz I. [et al.]. Levantine cranium from Manot Cave (Israel) foreshadows the first European modern humans // Nature. 2015. Vol. 520. P. 216-219.

Israde-Alcántara I. [et al.]. Evidence from central Mexico supporting the Younger Dryas extraterrestrial impact hypothesis // Proceedings of the National Academy of Sciences. 2012. № 109 (13). P. E738-E747.

Shackleton N.J. The stratigraphic record of deep-sea cores and its implications for the assessment of glacials, interglacials, stadials, and interstadials in the mid-Pleistocene // After the Australopithecines: Stratigraphy, ecology, and culture change in the Middle Pleistocene. Hague: Mouton Publishers, 1975. P. 1-24.

\section{References}

Baskin, L.M. (1989). Osobennosti morfologii i ekologii lesnykh i tundrovykh severnykh oleney [Features of the morphology and ecology of forest and tundra reindeer]. In Lesnoy severnyy olen Fennoskandii. Petrozavodsk, KFAN SSSR. 1989, pp. 86-91.

Bondarev, A.A., Kassal, B.Yu. (2004). Teriofauna i prirodnyye kompleksy pleystotsena Verkhneoshskoy paleodoliny [Theriofauna and natural complexes of the Pleistocene of the 
Verkhneoshsky Paleodolina]. In Kassal B.Yu. (Ed.) Trudy zoologicheskoy komissii ORO RGO. Yezhegodnik: Mezhvuzovskiy sbornik nauchnykh trudov. Omsk, Izdatel-Poligrafist. Iss. 1, pp. 149-158.

Bondarev, A.A., Kassal, B.Yu. (2005). Pleystotsenovaya teriofauna Krutinskogo rayona Omskoy oblasti [Pleistocene theriofauna of the Krutinsky district of the Omsk region] In Yestestvennyye nauki i ekologiya: Yezhegodnik: Mezhvuzovskiy sbornik nauchnykh trudov. Omsk, OmGPU. Iss. 9, pp. 91-97.

Bondarev A.A., Kassal B.Yu. (2009). Istoriya i perspektivy razvitiya teriofauny Srednego Priirtyshya [History and development prospects of theriofauna of the Middle Irtysh region]. In Vestnik Orenburgskogo gosudarstvennogo universiteta. No. 6 (100), pp. 86-88.

Constable, D. (1978). Neandertaltsy [Neanderthals] / Perevod s angl. I.G. Gurovoy. Moscow, Mir. 160 p.

Flerov, K.K. (1955). Osnovnyye cherty formirovaniya fauny mlekopitayushchikh chetvertichnogo perioda v severnom polusharii [The main features of the formation of the Quaternary mammalian fauna in the northern hemisphere]. In Tr. Komissii po izucheniyu chetvertichnogo perioda. Vol. 12, pp. 121-126.

Flerov, K.K. (1976). Istoriya bizonov i prichiny izmeneniya ikh arealov [The history of bisons and the reasons for changes in their ranges] In Istoriya biogeotsenozov SSSR v golotsene. Moscow, Nauka, pp. 166-175.

Formozov, A.N. (1990). Snezhnyy pokrov v zhizni mlekopitayushchikh i ptits [Snow cover in the life of mammals and birds]. Moscow, Izd-vo MGU. 1990. 286 p.

$\mathrm{Fu}, \mathrm{Q}$. [et al.] (2014). Genome sequence of a 45,000-year-old modern human from western Siberia. In Nature. Vol. 514, pp. 445-449.

Gibbons, A. (2014). Oldest Homo sapiens genome pinpoints Neandertal input. In Science. No. 343 (6178), p. 1417.

Gill, J.L. [et al.]. (2009). Pleistocene megafaunal collapse, novel plant communities, and enhanced fire regimes in North America. In Science. No. 326 (5956), p. 1100-1103.

Hershkovitz, I. [et al.]. (2015). Levantine cranium from Manot Cave (Israel) foreshadows the first European modern humans. In Nature. Vol. 520, pp. 216-219.

Israde-Alcántara, I. [et al.]. (2012). Evidence from central Mexico supporting the Younger Dryas extraterrestrial impact hypothesis. In Proceedings of the National Academy of Sciences. No 109 (13), pp. E738-E747.

Kassal, B.Yu. (2009). 60 sekund po parku, kotorogo ne bylo (XXI puteshestvie omskogo naturalista) [60 seconds in the Park, which was not (XXI journey of the Omsk naturalist)]. Omsk, Pervopechatnik. $166 \mathrm{p}$.

Kassal, B.Yu. (2014). “Oskolki” pleystotsenovoy megafauny v stepyakh Srednego Priirtyshya ["Fragments" of the Pleistocene megafauna in the steppes of the Middle Irtysh]. In Stepnoy byulleten. No. 42, pp. 45-51.

Kassal, B.Yu. (2014). Dikiye kopytnyye na stepnoy territorii Srednego Priirtyshya [Wild ungulates in the steppe territory of the Middle Irtysh]. In Stepnoy byulleten. No. 40, pp. 44-47.

Kassal, B.Yu. (2014). Dikiye loshadi Srednego Priirtyshya [Wild horses of the Middle Irtysh Region]. In Tabunnoye konevodstvo na yuge Sredney Sibiri: Materialy nauchno-prakticheskoy konferentsii (5-8 avgusta 2014 g. Abakan) / FANO RF, FGBNU "NII agrarnykh problem Khakasii”, FGBNU "VNII konevodstva”, FGBNU “Tuvinskiy NII selskogo khozyaystva", FGBOU VPO “Tuvinskiy GU”. Abakan, pp. 39-43.

Kassal, B.Yu. (2016). Praktika zagonnykh gruppovykh okhot na beregakh sibirskikh rek v pleystotsene [The practice of driven group hunting on the banks of Siberian rivers in the Pleistocene]. In Omskiy nauchnyy vestnik. Seriya "Obshchestvo. Istoriya. Sovremennost". No. 1, pp. 38-48.

Kassal, B.Yu. (2019). Kultura zagonnykh gruppovykh okhot $\mathrm{v}$ traditsionnom obshchestve neolita [The culture of corral group hunts in the traditional Neolithic society]. In Uvarov P.B. (Ed.) Traditsionnyye obshchestva: neizvestnoye proshloye: materialy XV Mezhdunarodnoy nauchno- 
prakticheskoy konferentsii, g. Chelyabinsk, 15.05.2019. Chelyabinsk: Izd-vo Yuzhno-Ural. gos. guman.-ped. un-ta, pp. 220-228.

Kassal, B.Yu. (2019). Roli uchastnikov zagonnykh gruppovykh okhot v obshchestve neolita [Roles of participants in corral group hunts in Neolithic society] In XIII Kongress antropologov i etnologov Rossii: sb. materialov. Kazan, 2-6 iyulya 2019 g. / otv. red. M.Yu. Martynova. Moscow; Kazan: IEA RAN, KFU, Institut istorii im. Sh. Mardzhani AN RT, pp. 149.

Kassal B.Yu. (2020). Okhota na mamonta kak legenda kultury [Hunting for a mammoth as a legend of culture]. In Vestnik OmGPU, Gumanitarnyye issledovaniya. No. 1 (26), pp. 14-18.

Koch P.L., Barnosky A.D. (2006). Late Quaternary extinctions: state of the debate. In Ann. Rev. Ecol. Evol. Syst, pp. 215-250.

Pääbo, S. (2018). Neandertalets.V poiskakh ischeznuvshikh genomov [Neanderthal. In search of disappeared genomes] / Perevod s angl. Ye.B. Naymark. Moscow, AST. 416 p.

Pospelov, Ye.M. Sibir [Siberia] (2002). In Ageeva P.A. (Ed.) Geograficheskiye nazvaniya mira: Toponimicheskiy slovar. Moscow: Russkiye slovari, Astrel, AST, p. 475.

Razhev, D.I., Kosintsev, P.A., Kuzmin, Ya.V. (2010). Pleystotsenovaya tarannaya kost (os talus) cheloveka s mestonakhozhdeniya Baygara (tsentr Zapadnoy Sibiri) [Pleistocene talus (os talus) of a person from the location of Baigar (center of Western Siberia)]. In Vestnik arkheologii, antropologii i etnografii. No. 1 (12), pp. 119-131.

Shackleton, N.J. (1975). The stratigraphic record of deep-sea cores and its implications for the assessment of glacials, interglacials, stadials, and interstadials in the mid-Pleistocene. In After the Australopithecines: Stratigraphy, ecology, and culture change in the Middle Pleistocene. Hague: Mouton Publishers, 1975, pp. 1-24.

Shipman, P. (2016). Zakhvatchiki. Lyudi i sobaki protiv neandertaltsev [Invaders. People and dogs against Neanderthals] / Perevod s angl. Dm. Lazareva. Moscow, Alpina non-fikshn; Izdatelstvo LKI. 296 p.

Vorobyevskaya, Ye.A, Bondarev, A.Ya., Suvorov A.P., Politov D.V. (2011). Issledovaniya filogeografii volka (Canis lupus L.) Yuzhnoy Sibiri i Krasnoyarskogo kraya metodom mikrosatellitnykh markerov [Studies of the phylogeography of a wolf (Canis lupus L.) in Southern Siberia and the Krasnoyarsk Territory by the method of microsatellite markers]. In Teriofauna Rossii i sopredelnykh territoriy. Mezhdunarodnoye soveshchaniye (IX sezd Teriologicheskogo obshchestva pri RAN). Moscow, TNI KMK, p. 104.

Zhitelev, R.A., Kassal, B.Yu. (2012). Rog bizona (Bison priscus) v kachestve osnovy mnogofunktsionalnogo artefakta [Horn of a bison (Bison priscus) as the basis of a multifunctional artifact]. In Kassal B.Yu. (Ed.) Omskaya biologicheskaya shkola: Mezhvuzovskiy sbornik nauchnykh trudov. Yezhegodnik. Omsk, OmGPU, 2012. Iss. 9, pp. 149-160. 